\section{Physiological and Nutritional Responses of 'HB' Pummelo [Citrus grandis (L.) Osbeck 'Hirado Buntan'] to the Combined Effects of Low pH Levels and Boron Deficiency}

\author{
Gaofeng Zhou, Bixian Li, Jianmei Chen, Fengxian Yao, Guan Guan,
} and Guidong Liu

National Navel Orange Engineering Research Center, College of Navel

Orange, Gannan Normal University, Ganzhou 341000, China

\section{Qingjiang Wei \\ College of Agronomy, Jiangxi Agricultural University, Nanchang 330045, China}

Additional index words. boron starvation, citrus, growth, nutrient concentration, soil acidification, visual deficiency symptom

\begin{abstract}
Soil acidification and boron (B) starvation are two dominant abiotic stress factors impacting citrus production in the red soil region of southern China. To evaluate the combined effects of low $\mathrm{pH}$ and $\mathrm{B}$ deficiency on plant growth, gas exchange parameters, and the concentrations of $B$ and other mineral nutrients, ' $\mathrm{HB}$ ' pummelo seedlings were treated under $\mathrm{B}$ deficiency $\left(0 \mu \mathrm{M} \mathrm{H}_{3} \mathrm{BO}_{3}\right)$ or adequate $\mathrm{B}\left(23 \mu \mathrm{M} \mathrm{H}_{3} \mathrm{BO}_{3}\right)$ conditions at various low $\mathrm{pH}$ levels $(4.0,5.0$, and 6.0$)$. The seedlings were grown with modified half-strength Hoagland's solution under greenhouse conditions for 12 weeks. Plant biomass, leaf area, seedling height, and root traits were remarkably inhibited by low $\mathrm{pH}$ and $\mathrm{B}$ deficiency stresses, and these parameters were extremely reduced with the decrease in $\mathrm{pH}$ levels. After 12 weeks of treatment, typical stress symptoms associated with $B$ deficiency in citrus leaf were observed, with more severe symptoms observed at pH 4.0 and 5.0 than at pH 6.0. Leaf gas exchange parameter measurements showed that leaf photosynthesis was significantly inhibited under both low $\mathrm{pH}$ and B-deficient conditions. Notably, the lower the $\mathrm{pH}$ level, the greater the inhibition under both normal and deficient $B$ conditions. Further investigations of the mineral nutrient concentrations showed that under both low $\mathrm{pH}$ and $\mathrm{B}$ deficiency, the concentrations of $\mathrm{B}$ and other mineral nutrients were influenced remarkably, particularly at $\mathrm{pH} 4.0$ and 5.0. The physiological and nutritional results of the 'HB' pummelo seedlings indicated that low pH can exacerbate the effects of $B$ deficiency to a certain extent.
\end{abstract}

Abiotic stresses, such as nutrient disorder and soil acidification, are dominant soil factors that affect plant performance. It is well known that B is an essential micronutrient for vascular plants (Marschner, 1995), and it has an important role in various plant metabolic pathways (Bolaños et al., 2004; Brown et al.,

Received for publication 12 Nov. 2019. Accepted for publication 27 Dec. 2019

Published online 21 February 2020

This work was supported by the National Natural Science Foundation of China (No.31960573 and 31760606), and Science Foundation Project of Jiangxi Provincial (No.20192BAB204016). Science and Technology Support Program of Jiangxi Province (20152ACF60007). We thank LetPub (www.letpub.com) for its linguistic assistance during the preparation of this manuscript.

F.Y. is the corresponding author. E-mail: fengxianyao@ aliyun.com

This is an open access article distributed under the CC BY-NC-ND license (https://creativecommons. org/licenses/by-nc-nd/4.0/). results from the removal of plant materials, acid deposition, and nitrogen $(\mathrm{N})$ cycling in the soil (Guo et al., 2010; Zhou et al., 2014). Soil acidification causes not only soil aluminum (Al) and manganese (Mn) toxicity but also phosphorus (P), molybdenum (Mo), calcium $(\mathrm{Ca})$, and magnesium $(\mathrm{Mg})$ deficiency in plants (Russell, 2006; Zhang et al., 2009). During the past 30 years, Chinese agriculture has intensified and chemical fertilizer application has increased. In particular, the wide application of $\mathrm{N}$ fertilizer has become a major cause of soil acidification in China. Four billion hectares ( $\approx 30 \%$ of ice-free soils) of soil globally are acidic (Sumner and Noble, 2003). Southeast and Pacific Asia and South America are affected worst, with more than $50 \%$ of the total land in these areas harboring low pH soils. Acidic soils are mostly associated with forests $(\approx 66 \%)$ and pastures $(\approx 11 \%)$, with a relatively small proportion (5\%) supporting crops. Although Citrus can be cultivated in soils covering a wide range of $\mathrm{pH}$ and are tolerant to acidic soils (Zhang et al., 2018), soil acidification has become a serious problem for citrus cultivation in China. Li et al. (2015) reported that soil acidification was a major problem in 'Guanximiyou' pummelo (Citrus grandis) orchards in Pinghe county, which is in the southern region of Fujian province in China, with an average $\mathrm{pH}$ of 4.34. Approximately one-third of the total area of citrus orchards in Jiangxi province (one of the main citrus-producing regions in China) suffers from acidic soil (Chen et al., 2010).

Citrus is an important fruit crop produced throughout tropical and subtropical regions of the world. However, citrus production can be seriously affected by B deficiency (Chen et al., 2012; Sheng et al., 2008). Although citrus plants are not classified as the most sensitive species to B deficiency, the occurrence of $B$ deficiency has been reported in the major citrus-producing countries of the world, such as Spain, the United States, Brazil, and China (Sheng et al., 2009; Shorrocks, 1997). East and south China are important citrus-growing regions, but the soil $\mathrm{B}$ level is low (hot water extraction $\mathrm{B}<0.25$ $\mathrm{mg} \cdot \mathrm{kg}^{-1}$ ) (Sheng et al., 2008). In these regions, corky split veins in the leaves are frequently visible in pummelo (Citrus Grandis). Based on 1400 soil samples from these regions, the soil $\mathrm{pH}$ is generally neutral to acidic (4.0-7.0), and the average $\mathrm{pH}$ is 4.5 (Liang et al., 2010). The $\mathrm{pH}$ of a soil solution is known to affect B adsorption (Goldberg et al., 2000) and B availability in plants (Marschner, 1995). Soil pH changes affect B speciation [i.e., $\mathrm{B}(\mathrm{OH})_{3}$ vs. $\mathrm{B}(\mathrm{OH})_{4}{ }^{-}$] and soil adsorption processes, ultimately affecting B absorption by plants (Goldberg et al., 2000). As $\mathrm{pH}$ increases, the rate of $\mathrm{B}$ uptake is dramatically reduced, particularly when the $\mathrm{pH}$ exceeds 8 (Läuchli and Grattan, 2012; Marschner, 1995), at which point the speciation of $\mathrm{B}$ starts to progressively shift from boric acid $\mathrm{B}(\mathrm{OH})_{3}$ to anionic borate $\mathrm{B}(\mathrm{OH})_{4}$ (equal activities of the two species occur at $\mathrm{pH}$ 9.3). The effect of liming on reducing $\mathrm{B}$ 

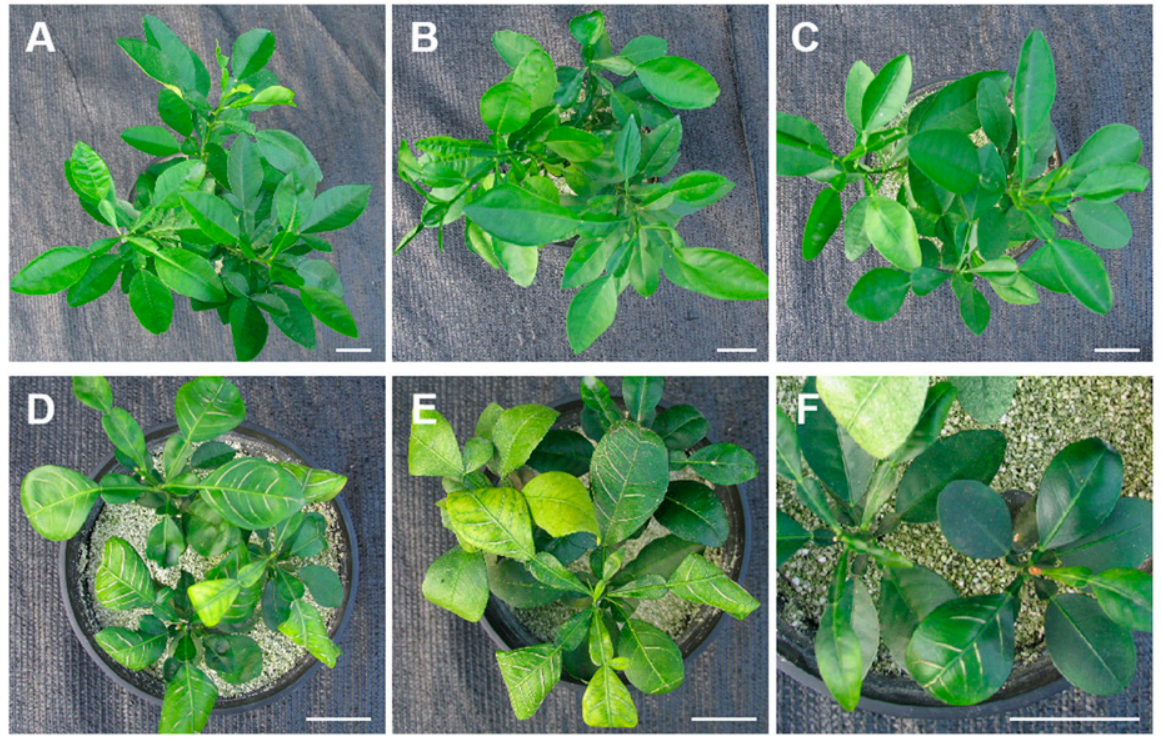

Fig. 1. Symptoms in the leaf of 'HB' pummelo seedlings caused by low $\mathrm{pH}$ and boron (B) deficiency. All the plants were grown under sand culture conditions and treated for 12 weeks. (A) Control, normal B, $\mathrm{pH}$ 6.0. (B) Normal B, pH 5.0. (C) Normal B, pH 4.0. (D) B deficiency, pH 6.0. (E) B deficiency, $\mathrm{pH}$ 5.0. (F) B deficiency, $\mathrm{pH} 4.0$.

availability in plants is well-known for agricultural crops, and it is at least partly caused by the increased absorption of $\mathrm{B}$ in the soil as the $\mathrm{pH}$ increases (Gupta et al., 1985). Therefore, it is important to clarify the mechanisms of $\mathrm{B}$ absorption and distribution in citrus under different acidic soil $\mathrm{pH}$ conditions. Our study aimed to determine the combined effects of low $\mathrm{pH}$ and $\mathrm{B}$ deficiency on the performance of ' $\mathrm{HB}$ ' pummelo seedlings, including plant growth, gas exchange, and mineral nutrient accumulation.

\section{Materials and Methods}

Plant materials and treatment. 'HB' pummelo [Citrus grandis (L.) Osbeck 'Hirado Buntan'] seedlings were used in this experiment. The seed germination and seedling culture of 'HB' pummelo were conducted according to Zhou et al. (2014). Thirty days after planting, a total of 108 seedlings of uniform size were selected. According to published methods (Papadakis et al., 2004; Sheng et al., 2009), the seedlings were washed with deionized water to remove surface contaminants and then transplanted to 5-L black pots containing B-free medium composed of quartz sand:perlite $(1: 1, \mathrm{v} / \mathrm{v})$. Experiments were performed in a growth chamber with a light/dark regime of $14 / 10$ h, $28 / 22{ }^{\circ} \mathrm{C}, 75 \%$ relative humidity, and light intensity of $800 \mu \mathrm{mol} \cdot \mathrm{m}^{-2} \cdot \mathrm{s}^{-1}$ of $P A R$. The plants were precultured with half-strength Hoagland's No. 2 nutrient solution for 2 to 3 weeks until the appearance of the new leaf. Then, they were irrigated twice per week with a modified Hoagland's No. 2 nutrient solution with $0 \mu \mathrm{M} \mathrm{H}_{3} \mathrm{BO}_{3}$ [B deficiency treatment (BD)] or $23 \mu \mathrm{M} \mathrm{H}{ }_{3} \mathrm{BO}_{3}$ [control plants $(\mathrm{CK})]$, and the $\mathrm{pH}$ of these nutrient solutions was adjusted to 4.0 (BD4 and CK4), 5.0 (BD5 and CK5), and 6.0 (BD6 and CK6) with $0.1 \mathrm{M} \mathrm{HCl}$ or $0.1 \mathrm{M} \mathrm{KOH}$. The treatments started on 25 May 2017 and ended on 16 Aug. 2017, when the visible symptom (corky split vein) of B deficiency had appeared. The modified B-free full-strength Hoagland's No. 2 nutrient solution contained $6 \mathrm{~mm} \mathrm{KNO}_{3}, 4 \mathrm{~mm} \mathrm{Ca}\left(\mathrm{NO}_{3}\right)_{2}, 1 \mathrm{~mm} \mathrm{NH}_{4} \mathrm{H}_{2}$ $\mathrm{PO}_{4}, 2 \mathrm{~mm} \mathrm{MgSO}_{4}, 9 \mu \mathrm{M} \mathrm{MnCl} 2,0.8 \mu \mathrm{M}$ $\mathrm{ZnSO}_{4}, 0.3 \mu \mathrm{M} \mathrm{CuSO}, 0.01 \mu \mathrm{M} \mathrm{H}_{2} \mathrm{MoO}_{4}$, and $50 \mu \mathrm{M}$ Fe-EDTA (Hoagland and Arnon, 1950).

Sampling and plant growth parameter measurements. At the end of the experiment, nine plants per treatment were randomly harvested, rinsed in deionized water, and blotted carefully with tissue paper. The materials were then divided into the leaf, stem, and root. Leaf area $\left(\mathrm{cm}^{2}\right)$ was determined using a leaf area meter (Li-3100C; LI-COR Biosciences Inc., Lincoln, NE). The fresh materials were placed in a forced air oven at $105{ }^{\circ} \mathrm{C}$ for $15 \mathrm{~min}$, followed by $75^{\circ} \mathrm{C}$ until constant weights were reached to determine their dry weights $(\mathrm{mg})$ for the calculation of the shoot dry weight/root dry weight $(\mathrm{S} / \mathrm{R})$ ratio. Then, all the dried samples were ground into a fine powder for the determination of $B$ and other mineral nutrient concentrations in the tissues. Seedling height $(\mathrm{cm})$ and taproot length $(\mathrm{cm})$ were measured using a scaled ruler.

Leaf gas exchange measurements. After 6 weeks of treatment, gas exchange parameters, including the photosynthetic rate $\left(\mathrm{P}_{\mathrm{n}} ; \mu \mathrm{mol} \mathrm{CO}_{2} \mathrm{~m}^{-2} \cdot \mathrm{s}^{-1}\right)$, stomatal conductance $\left(g_{\mathrm{S}} ; \mathrm{mmol} \mathrm{m}{ }^{-2} \cdot \mathrm{s}^{-1}\right)$, intercellular $\mathrm{CO}_{2}$ concentration $\left(C_{\mathrm{i}} ; \mu \mathrm{mol} \cdot \mathrm{mol}^{-1}\right)$, and transpiration rate $\left(E ;\right.$ mmol $\left.\mathrm{H}_{2} \mathrm{O} \mathrm{m} \mathrm{m}^{-2} \cdot \mathrm{s}^{-1}\right)$, of all plants were measured using a $\mathrm{Li}-6400$ device (LI-COR Biosciences Inc.) between 9:30 and 11:30 AM on a clear day. During all of these measurements, the leaf temperature and relative humidity were $28.9 \pm 1.4{ }^{\circ} \mathrm{C}$ and
$71.6 \pm 2.8 \%$, respectively. The controlled light intensity was $1000 \pm 8.7 \mu \mathrm{mol} \cdot \mathrm{m}^{-2} \cdot \mathrm{s}^{-1}$ and the controlled $\mathrm{CO}_{2}$ concentration was $400 \mu \mathrm{mol} \cdot \mathrm{mol}^{-1}$. Measurements were performed according to the method described by Sheng et al. (2009).

Root morphology analysis. Nine seedlings were randomly sampled in each treatment group and rinsed with deionized water. For the root morphology analysis, the root samples were scanned using an Epson digital scanner (Expression 10000XL 1.0; Epson Inc., Nagano, Japan), and the image was analyzed using WinRhizo Pro (S) v. 2009c (Regent Instruments Inc., Quebec, Canada) software. The determined traits included total root length, root surface area, root volume, and root number.

Determination of mineral nutrients. The mineral nutrient concentrations of $\mathrm{P}$, potassium $(\mathrm{K}), \mathrm{Ca}, \mathrm{Mg}$, iron (Fe), Mn, zinc $(\mathrm{Zn})$, and $\mathrm{B}$ in the different plant tissues were determined following the method described by Storey and Treeby (2000). Briefly, $0.50 \mathrm{~g}$ of each sample was dry-ashed in a muffle furnace at $500{ }^{\circ} \mathrm{C}$ for $6 \mathrm{~h}$, followed by dissolution in $0.1 \mathrm{~N} \mathrm{HCl}$. The mineral nutrients concentration was then determined using inductively coupled plasma mass spectrometry 7900 (ICP-MS7900; Agilent Technologies Inc., Santa Clara, CA).

Experimental design and statistical analysis. The experiment was set up in a completely randomized $3 \times 2$ factorial design with three nutrient solution $\mathrm{pH}$ values $(\mathrm{pH}=$ $4.0,5.0$, and 6.0) and two B treatments ( 0 and $23 \mu \mathrm{M}$ of $\left.\mathrm{H}_{3} \mathrm{BO}_{3}\right)$. The values are presented as the means \pm SE of nine seedlings (three plants in each pot, three repeats). The data were subjected to an analysis of variance using SAS (SAS 8.1; SAS Institute Inc., Cary, NC), and the differences were compared using Duncan's test with a significance level of $P<0.05$.

\section{Results}

Visible symptoms and plant growth. After 12 weeks of low $\mathrm{pH}$ and B deficiency treatment, visible symptoms appeared on the leaves of the ' $\mathrm{HB}$ ' pummelo seedlings under B deficiency at all $\mathrm{pH}$ levels, whereas no remarkable symptom was observed under normal B conditions (Fig. 1). The main visible symptom under B deficiency was vein swelling or cracking (corky split vein), which are typical symptoms of citrus suffering from B deficiency stress. This visible symptom was initially observed in the adult leaves, but not in the young leaves. However, as the treatment duration progressed, the vein swelling or cracking symptoms appeared in the young leaves, and the mature leaves started yellowing under B deficiency. In addition, more severe leaf symptoms were observed at $\mathrm{pH} 5.0$ than at 6.0 (Fig. 1D and E). Interestingly, the leaf symptoms at $\mathrm{pH} 4.0$ were not as severe as those at $\mathrm{pH} 5.0$ or 6.0 (Fig. 1D-F).

Compared with the control plants (normal $\mathrm{B}$ and $\mathrm{pH}$ 6.0), B deficiency treatment 
Table 1. Combined effects of low $\mathrm{pH}$ and boron (B) deficiency on plant growth, biomass, and the root/shoot (R/S) ratio of 'HB' pummelo seedlings.

\begin{tabular}{|c|c|c|c|c|c|}
\hline Treatments & $\mathrm{pH}$ & Seedling ht $(\mathrm{cm})$ & Leaf area $\left(\mathrm{cm}^{2} /\right.$ plant $)$ & Biomass (g/plant DW) & $\mathrm{R} / \mathrm{S}$ ratio \\
\hline \multirow{2}{*}{$\overline{\text { Normal B }\left(0.25 \mathrm{mg} \cdot \mathrm{L}^{-1}\right)}$} & 6.0 & $38.17 \pm 3.09 \mathrm{~A} \mathrm{a}$ & $655.12 \pm 79.53 \mathrm{~A} \mathrm{a}$ & $9.79 \pm 1.22 \mathrm{~A} \mathrm{a}$ & $0.34 \pm 0.02 \mathrm{C}$ \\
\hline & 4.0 & $28.73 \pm 1.24 \mathrm{~A} \mathrm{~b}$ & $416.76 \pm 32.94 \mathrm{~B} \mathrm{c}$ & $7.44 \pm 0.53 \mathrm{~B} \mathrm{~b}$ & $0.28 \pm 0.02 \mathrm{C}$ \\
\hline \multirow[t]{2}{*}{ Deficient B (0 mg. $\left.\mathrm{L}^{-1}\right)$} & 6.0 & $16.23 \pm 1.13 \mathrm{~B} \mathrm{a}$ & $203.60 \pm 30.67 \mathrm{D}$ a & $5.25 \pm 0.72 \mathrm{C} \mathrm{a}$ & $0.41 \pm 0.04 \mathrm{~B} \mathrm{~b}$ \\
\hline & 4.0 & $14.72 \pm 0.79 \mathrm{~B} \mathrm{~b}$ & $101.48 \pm 12.23 \mathrm{E} \mathrm{b}$ & $3.62 \pm 0.19 \mathrm{D} \mathrm{c}$ & $0.58 \pm 0.04$ \\
\hline
\end{tabular}

$F$ values

$\mathrm{pH}$ levels $(\mathrm{P})$

$\mathrm{B}$ treatment $(\mathrm{B})$

$15.99 * * *$

404.71***

$8.00^{* *}$

$13.34^{* * * *}$
$186.62^{* * *}$
$2.48^{\mathrm{Ns}}$

$18.17 * * *$
$218.27 * * *$

1.77 Ns

$\mathrm{P} \times \mathrm{B}$

$2.48^{\mathrm{Ns}}$

$1.40^{\mathrm{Ns}}$

$41.67 * * *$ $6.61 * *$

$F$ values for the $\mathrm{pH}$ levels, B treatment, and their interactions are shown. Significance of analysis of variance: ${ }^{*} P<0.05 ; * * P<0.01 ; * * * P<0.001 ;$ NS $=$ nonsignificant.

All plants were grown in sand culture conditions and treated for 12 weeks. Data are presented as mean of three replicates $(\mathrm{n}=3)$; samples from three plants were collected for each replicate. Different small and capital letters behind the mean values indicate significant differences $(P<0.05)$ between the different $\mathrm{pH}$ levels and different $\mathrm{B}$ concentration treatments, respectively.
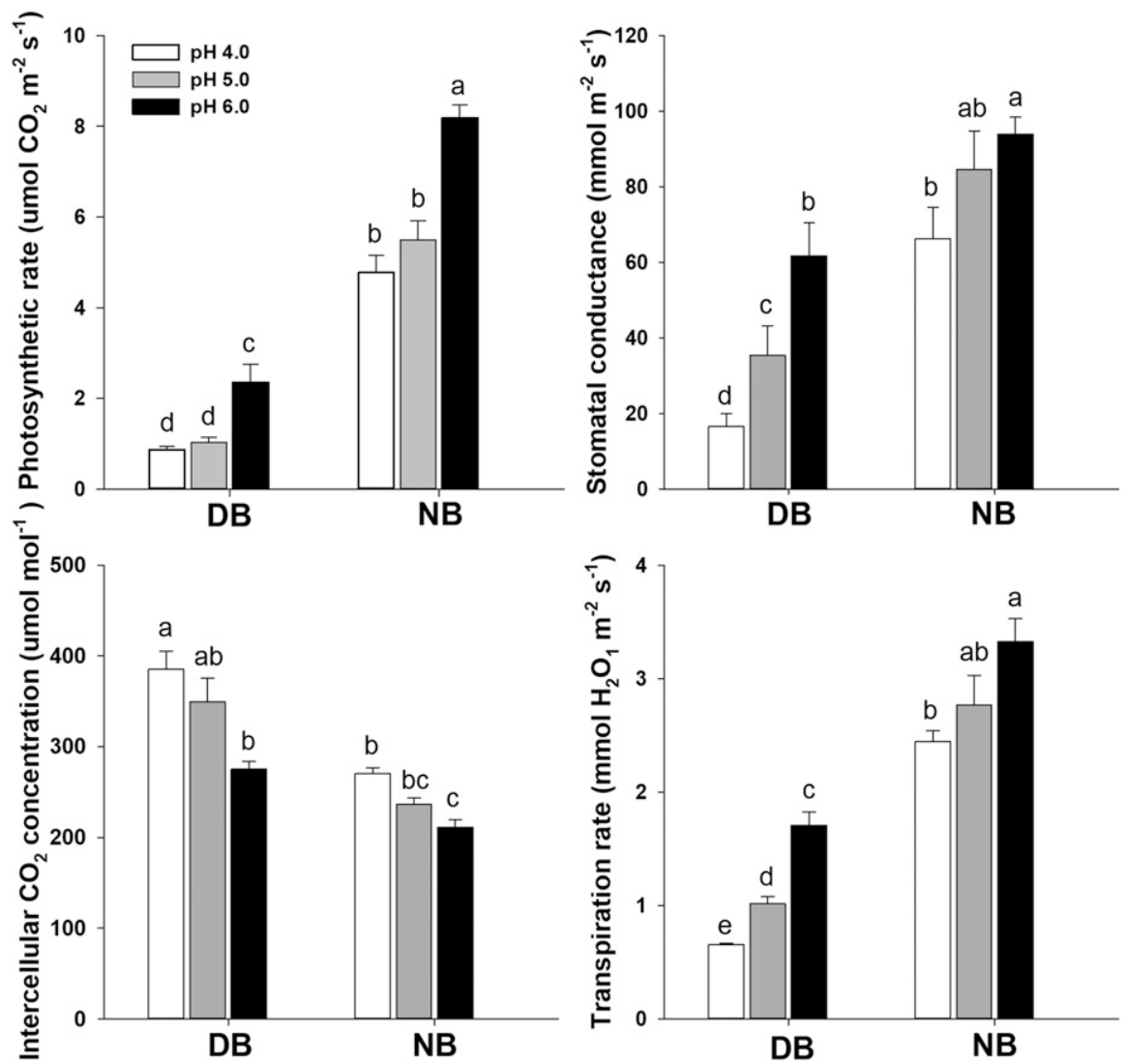

Fig. 2. The combined effects of low $\mathrm{pH}$ and boron (B) deficiency on the (A) photosynthetic rate $\left(\mu \mathrm{mol} \mathrm{CO}_{2}\right.$ $\left.\mathrm{m}^{-2} \cdot \mathrm{s}^{-1}\right),(\mathbf{B})$ stomatal conductance $\left(\mathrm{mmol} \cdot \mathrm{m}^{-2} \cdot \mathrm{s}^{-1}\right),(\mathbf{C})$ intercellular $\mathrm{CO}_{2}$ concentration $\left(\mu \mathrm{mol} \cdot \mathrm{mol}^{-1}\right)$ and (D) transpiration rate $\left(\mathrm{mmol} \mathrm{H}_{2} \mathrm{O}_{1} \mathrm{~m}^{-2} \cdot \mathrm{s}^{-1}\right)$ of ' $\mathrm{HB}$ ' pummelo seedlings. All the plants were grown under sand culture conditions and treated for 12 weeks. Data are presented as means \pm SE of nine replicates ( $\mathrm{n}=9$; one plant for each replicate). Different small letters above the bars indicate significant differences $(P<0.05)$ between the different $\mathrm{pH}$ levels and different boron concentration treatments. $\mathrm{DB}=$ deficient $\mathrm{B}$ concentration; $\mathrm{NB}=$ normal boron concentration.

significantly inhibited the seedling height, leaf area, and biomass of the seedlings at all $\mathrm{pH}$ levels. Conversely, the R/S (root/shoot) ratios were significantly increased by $\mathrm{B}$ deficiency treatment (Table 1). Similarly, low $\mathrm{pH}$ also influenced the plant growth. Under both normal and deficient $\mathrm{B}$ conditions, the seedling height, leaf area, and biomass were more significantly inhibited at $\mathrm{pH} 4.0$ and 5.0 than at $\mathrm{pH}$ 6.0. The $\mathrm{R} / \mathrm{S}$ ratios were significantly decreased at $\mathrm{pH} 4.0$ under normal $\mathrm{B}$ conditions, whereas no remarkable differences were found at $\mathrm{pH} 5.0$ in comparison with the control plants. However, the highest R/S ratio was found at $\mathrm{pH} 4.0$ under $\mathrm{B}$ deficiency, and furthermore, no remarkable difference was detected between $\mathrm{pH} 5.0$ and 6.0 (Table 1).

Leaf gas exchange parameters. As shown in Fig. 2, the leaf gas exchange parameters were greatly influenced by B deficiency at all $\mathrm{pH}$ levels. Under the normal B concentration, $\mathrm{P}_{\mathrm{n}}, g_{\mathrm{S}}$, and $\mathrm{E}$ were higher at $\mathrm{pH} 6.0$ than at $\mathrm{pH}$ 4.0 and 5.0. However, for $C_{\mathrm{i}}$, the highest value was at $\mathrm{pH} 4.0$, and no significant difference was found between the other two $\mathrm{pH}$ values. Under $\mathrm{B}$ deficiency, $\mathrm{P}_{\mathrm{n}}, g_{\mathrm{S}}$, and $\mathrm{E}$ were significantly decreased at all $\mathrm{pH}$ levels compared with the control at the same $\mathrm{pH}$, whereas $C_{\mathrm{i}}$ was significantly increased (Table 2).

Root morphology traits. To further investigate the effects of low $\mathrm{pH}$ and $\mathrm{B}$ deficiency on seedling roots, the root morphological traits were examined. Under the normal B concentration, the primary root length, root volume, and root number at $\mathrm{pH} 4.0$ and 5.0 were inhibited significantly compared with the control plants at $\mathrm{pH} 6.0$; however, no remarkable difference was observed between $\mathrm{pH} 4.0$ and 5.0. Root total length and root surface area decreased dramatically at $\mathrm{pH}$ 4.0, whereas no significant decline was found at $\mathrm{pH} 5.0$ compared with $\mathrm{pH}$ 6.0. Under B deficiency conditions, except the primary root length, other root morphological traits such as root total length, root surface area, root volume, and root number of the seedlings were significantly decreased at all $\mathrm{pH}$ levels, whereas the root density was increased under the same conditions. Moreover, no significant differences were found in all root-related morphological traits of all $\mathrm{pH}$ levels (Fig. 3; Table 3).

Mineral nutrient concentration. For the main micronutrients ( $\mathrm{Fe}, \mathrm{Mn}, \mathrm{B}$, and $\mathrm{Zn}$ ), the $B$ concentration decreased significantly in all organs of the seedlings under B deficiency. The $\mathrm{B}$ concentration also decreased at $\mathrm{pH} 4.0$ in the leaf and root under normal $\mathrm{B}$ conditions, but not under deficient $\mathrm{B}$ conditions (Fig. 4A-C). Fe concentration decreased significantly under $\mathrm{B}$ deficiency stress in all organs, except in the leaf and stem at $\mathrm{pH}$ 4.0. The leaf and stem Fe concentration also decreased under low $\mathrm{pH}$ levels, especially at pH 4.0 (Fig. 4D-F). The impact of B deficiency stress on Mn tissue concentration was only detected at $\mathrm{pH} 6.0$ in the leaf and root. Furthermore, the Mn concentration in both the leaf and root was also decreased at $\mathrm{pH} 4.0$ under normal $\mathrm{B}$ conditions, but only in the root under B deficiency (Fig. 4G-I). The concentration of $\mathrm{Zn}$ decreased significantly in all organs at $\mathrm{pH} 4.0$ and 5.0 under both normal and B-deficient conditions, with the exception of the stem under B-deficient 
Table 2. $F$ values and levels of significance for $\mathrm{pH}$ levels, boron (B) deficiency treatment, and their interactions according to the analysis of variance (ANOVA) on leaf gas exchange parameters.

\begin{tabular}{|c|c|c|c|c|c|}
\hline \multirow[b]{2}{*}{ Variance source } & \multirow[b]{2}{*}{$\mathrm{df}$} & \multicolumn{4}{|c|}{ Leaf gas exchange parameters } \\
\hline & & $P_{n}$ & $g_{\mathrm{S}}$ & $C_{\mathrm{i}}$ & $E$ \\
\hline pH levels (P) & 2 & $69.68 * * *$ & $30.82 * * *$ & $56.59 * * *$ & $47.01 * * *$ \\
\hline $\mathrm{B}$ treatments (B) & 1 & $703.58 * * *$ & $145.41 * * *$ & $247.31 * * *$ & $409.66^{* * *}$ \\
\hline $\mathrm{P} \times \mathrm{B}$ & 2 & $6.35 * *$ & $2.26^{\mathrm{NS}}$ & $7.73 * *$ & $0.29^{\mathrm{Ns}}$ \\
\hline
\end{tabular}

Significance of ANOVA: $* P<0.05 ; * * P<0.01 ; * * * P<0.001$; NS $=$ nonsignificant.

$\mathrm{P}_{\mathrm{n}}=$ photosynthetic rate; $g_{\mathrm{S}}=$ stomatal conductance.
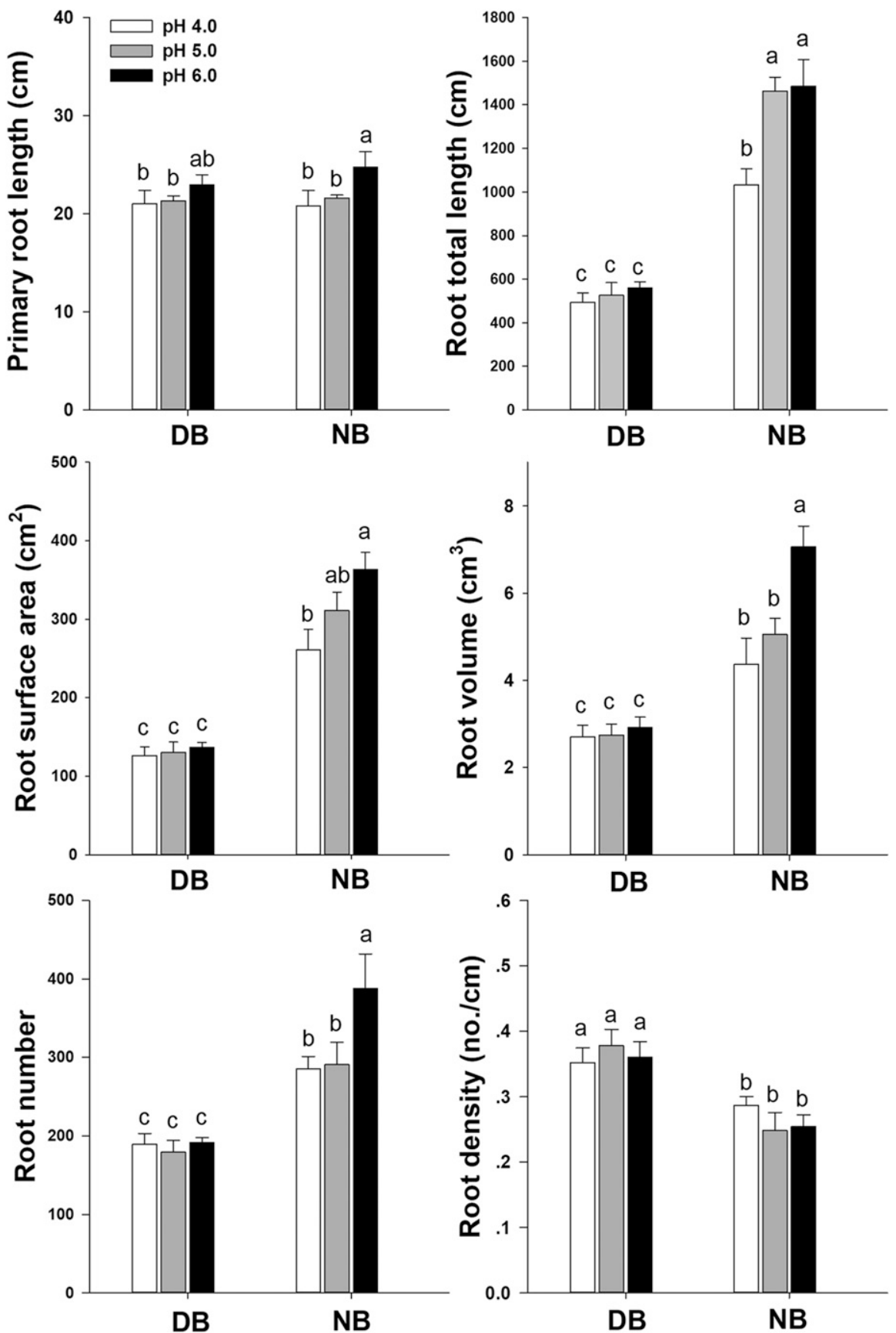

Fig. 3. The combined effects of low $\mathrm{pH}$ and boron (B) deficiency on the root morphology of the 'HB' pummelo seedlings. All plants were grown under sand culture conditions and treated for 12 weeks. Data are presented as means $\pm \mathrm{SE}$ of nine replicates $(\mathrm{n}=9$; one plant for each replicate). Different small letters above the bars indicate significant differences $(P<0.05)$ between the different $\mathrm{pH}$ levels and different $\mathrm{B}$ concentration treatments. $\mathrm{DB}=$ deficient $\mathrm{B}$ concentration; $\mathrm{NB}=$ normal boron concentration.

conditions. The leaf and stem $\mathrm{Zn}$ concentrations under normal $\mathrm{B}$ conditions were remarkably higher than those under B-deficient conditions (Fig. 4J-L).
The concentrations of mineral macronutrients $(\mathrm{P}, \mathrm{K}, \mathrm{Ca}$, and $\mathrm{Mg})$ in the leaves, stems, and roots of the seedlings are indicated in Fig. 5. The $\mathrm{P}$ concentrations decreased significantly in all organs at all $\mathrm{pH}$ levels under B-deficient conditions. The P concentrations also decreased significantly in the leaf, but not in the stem or the root, at $\mathrm{pH} 4.0$ and 5.0 under normal $\mathrm{B}$ conditions in comparison with the control plants. However, the low $\mathrm{pH}$ levels did not influence all organs under B-deficient conditions. The concentrations of $\mathrm{K}$ decreased with the decrease in $\mathrm{pH}$ in the root, whereas no significant difference was detected in the stem under both normal and deficient $\mathrm{B}$ conditions. There was no remarkable change in leaf $\mathrm{K}$ concentration among the different $\mathrm{pH}$ levels under Bdeficient conditions, whereas a significant decrease was observed at $\mathrm{pH} 4.0$ under normal conditions. However, the Ca concentrations did not change dramatically under the different $\mathrm{pH}$ levels, except in the root at $\mathrm{pH}$ 4.0. Additionally, the $\mathrm{Ca}$ concentration decreased significantly under $\mathrm{B}$ deficiency at $\mathrm{pH} 6.0$ in the leaf, at $\mathrm{pH} 5.0$ and 6.0 in the root, and at all $\mathrm{pH}$ levels in the stem. The $\mathrm{Mg}$ concentrations also decreased under B deficiency in the leaf at all $\mathrm{pH}$ levels and in the root at $\mathrm{pH} 5.0$ and 6.0. Low $\mathrm{pH}$ levels also decreased the $\mathrm{Mg}$ concentrations in the leaf and root under normal $\mathrm{B}$ conditions, but not under deficient $\mathrm{B}$ conditions.

\section{Discussion}

Physiological responses of citrus to low $\mathrm{pH}$ and $\mathrm{B}$ deficiency stress. Both $\mathrm{B}$ and $\mathrm{pH}$ are dominant soil factors that affect plant growth and development, and plant performance is significantly inhibited under low $\mathrm{pH}$ and/or B-deficient soil conditions. Therefore, it is important to understand the interaction of low $\mathrm{pH}$ and $\mathrm{B}$ deficiency and how plants respond to these abiotic stresses in field environments (Läuchli and Grattan, 2012; Smith et al., 2013).

In this study, the interactions of low $\mathrm{pH}$ and $\mathrm{B}$ deficiency were assessed to investigate their effects on 'HB' pummelo seedlings. At the end of our experiment, corky split veins were observed under B-deficient conditions (Fig. 1). Corky split vein is a typical symptom of citrus that have been proved in various citrus while suffering from B starvation stress (Han et al., 2008; Liu et al., 2011b; Yang et al., 2013, 2015; Zhou et al., 2014, 2015). Other symptoms were also observed under B deficiency at different $\mathrm{pH}$ values, with more severe symptoms observed at $\mathrm{pH} 4.0$ and $\mathrm{pH}$ 5.0 than at $\mathrm{pH} 6.0$ (Fig. 1). We also found that these symptoms appeared earlier at $\mathrm{pH} 5.0$ than at $\mathrm{pH} 4.0$ and $\mathrm{pH} 6.0$ (data not shown). These results suggest that citrus plants could 
Table 3. $F$ values and levels of significance for $\mathrm{pH}$ levels, boron (B) deficiency treatment, and their interactions according to the analysis of variance (ANOVA) on root morphological traits.

\begin{tabular}{|c|c|c|c|c|c|c|c|}
\hline \multirow[b]{2}{*}{ Variance source } & \multirow[b]{2}{*}{ df } & \multicolumn{6}{|c|}{ Root morphological traits } \\
\hline & & Primary root length & Total root length & Root surface area & Root volume & Root number & Root density \\
\hline$\overline{\mathrm{pH}}$ levels (P) & 2 & $4.65^{*}$ & $14.49 * * *$ & $4.92 *$ & $22.71 * * *$ & $3.99^{*}$ & $0.72^{\mathrm{NS}}$ \\
\hline B treatments (B) & 1 & $0.62^{\mathrm{NS}}$ & $251.72 * * *$ & $134.93 * * *$ & $185.85 * * *$ & $56.02 * * *$ & $54.58 * * *$ \\
\hline $\mathrm{P} \times \mathrm{B}$ & 2 & $0.523^{\mathrm{Ns}}$ & $7.55 * *$ & $3.50 *$ & $14.34 * * *$ & $2.51^{\mathrm{Ns}}$ & $1.41^{\mathrm{NS}}$ \\
\hline
\end{tabular}

Significance of ANOVA: $* P<0.05 ; * * P<0.01 ; * * * P<0.001$; NS $=$ nonsignificant.
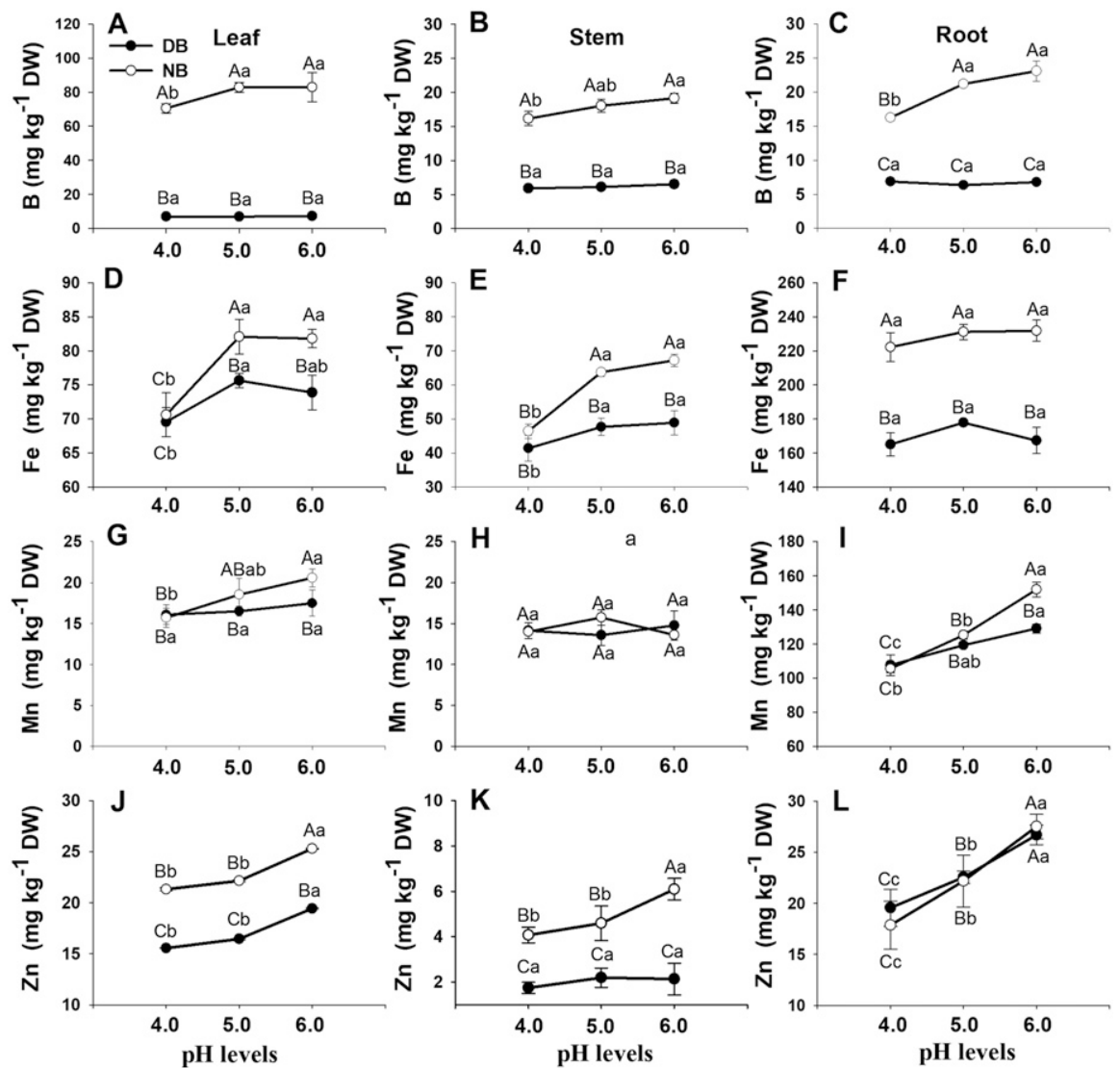

Fig. 4. The combined effects of low $\mathrm{pH}$ and boron (B) deficiency on the micronutrients of 'HB' pummelo seedlings. All plants were grown under sand culture conditions and treated for 12 weeks. Data are presented as means \pm SE of nine replicates $(n=9$; one plant for each replicate). Different small and capital letters above the vertical bars indicate significant differences $(P<0.05)$ between the different $\mathrm{pH}$ levels and different $\mathrm{B}$ concentration treatments, respectively. $\mathrm{DB}=$ deficient $\mathrm{B}$ concentration; $\mathrm{NB}=$ normal boron concentration.

be more sensitive to B deficiency stress at low soil $\mathrm{pH}$, but not at severe low soil $\mathrm{pH}$. Several field surveys have typically observed the corky split vein symptoms of B deficiency in 'Gannan' navel orange production regions of China, where the soil suffers from both acidification and B starvation (Chen et al., 2010; Liang et al., 2010; Sheng et al., 2009). Interestingly, our results showed that there was no significant difference in the B concentration among all $\mathrm{pH}$ values in all organs under B deficiency conditions (Fig. 4).

The effects of low $\mathrm{pH}$ and $\mathrm{B}$ deficiency stress on the performance of seedlings are typically assessed by changes in biomass. In our work, plant biomass decreased significantly under B-deficient conditions, especially at $\mathrm{pH} 4.0$ and 5.0. Moreover, plant biomass decreased with decreasing $\mathrm{pH}$ under normal B conditions (Table 1). As an essential micronutrient for vascular plants,
B has an important role in many metabolic pathways, and B deficiency will inhibit leaf expansion and root elongation by limiting cell enlargement and cell division (Dell and Huang, 1997; Marschner, 1995). Several previous studies have demonstrated that citrus plant biomass is also significantly inhibited by B deficiency (Han et al., 2012; Liu et al., 2011a; Mei et al., 2016; Zhou et al., 2014), and the results of this work corroborate those reported in the literature. The photosynthesis determination results showed that $\mathrm{P}_{\mathrm{n}}, C_{\mathrm{i}}, g_{\mathrm{S}}$, and $E$ were inhibited under low $\mathrm{pH}$ and $\mathrm{B}$ deficiency conditions (Fig. 2). These results suggested that the reduced biomass of the seedlings could have been caused by the increased photosynthetic efficiency, which corroborates similar research of other citrus fruits (Han et al., 2008, 2009; Long et al., 2017; Lu et al., 2014).
The underground parts of the plant are also influenced by low $\mathrm{pH}$ and/or B deficiency. Because the roots are the primary organs that penetrate the soil, they are directly affected by soil $\mathrm{pH}$ and nutrient starvation stress. To further investigate the effects of low $\mathrm{pH}$ and $\mathrm{B}$ deficiency on the root growth and development of the ' $\mathrm{HB}$ ' pummelo seedlings, root morphological traits were determined. Our results showed that root growth and development were significantly inhibited under low $\mathrm{pH}$ and $\mathrm{B}$ deficiency conditions (Fig. 3). It has been proven that plant roots are affected by $\mathrm{B}$ deficiency as a result of the role of B in cell wall construction (Dell and Huang, 1997; Marschner, 1995). Similar results have also been reported for the roots of other citrus ( $\mathrm{Li}$ et al., 2016; Mei et al., 2016; Zhou et al., 2014, 2015; Wu et al., 2018). Further plant anatomical investigations of the roots of citrus (Li et al., 2016; Mei et al., 2016; Zhou et al., 2015) suffering from B starvation stress have been performed, and these results indicated that the root cell and vessel walls were thickened under B deficiency conditions. Further research at the molecular level suggested that the expression of several genes coding for enzymes involved in cell wall metabolism were significantly altered in the roots of Arabidopsis (Camacho Cristóbal et al., 2008) and Citrus (Zhou et al., 2015) plants, such as xyloglucan endotransglycosylase/hydrolases, expansins, pectin methylesterases, and polygalacturonases. Therefore, based on the aforementioned research results, the inhibited root growth and development by B deficiency stress may be explained.

A dramatic morphological difference was also observed in the roots of the seedlings at low $\mathrm{pH}$ under both normal and deficient $\mathrm{B}$ conditions (Fig. 3). Several previous studies have shown that the plant root system architecture, which is evaluated based on root length, root surface area, root volume, and root tip, is significantly influenced by low soil pH (Zhou et al., 2018). The root system architecture is believed to have an important role in plant growth performance by adjusting the nutrient uptake from soil (Forde and Lorenzo, 2001; Hodge et al., 2009). Therefore, the root system architecture directly influenced the growth of the seedlings in this work (Fig. 3). Biochar amendment has recently been demonstrated to significantly increase the total absorptive surface area of the root system in citrus (Guo et al., 2016), and it can significantly increase the soil $\mathrm{pH}$ and organic matter (Major et al., 2010; Van Zwieten et al., 2010). 

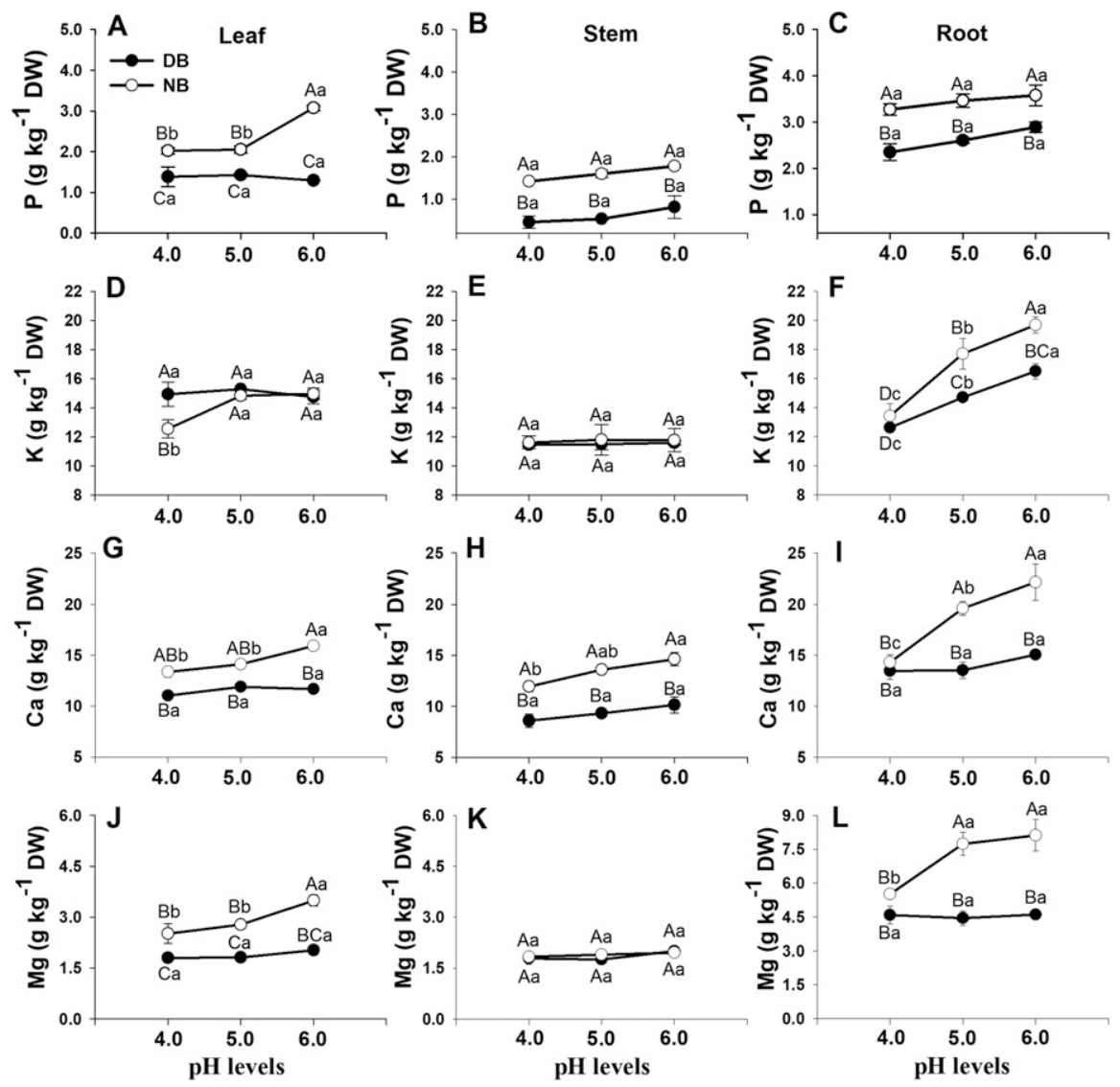

Fig. 5. The combined effects of low $\mathrm{pH}$ and boron (B) deficiency on macronutrients in 'HB' pummelo seedlings. All the plants were grown under sand culture conditions and treated for 12 weeks. Data are presented as means \pm SE of nine replicates $(n=9$; one plant for each replicate). Different small and capital letters above the vertical bars indicate significant differences $(P<0.05)$ between the different $\mathrm{pH}$ levels and different $\mathrm{B}$ concentration treatments, respectively. $\mathrm{DB}=$ deficient $\mathrm{B}$ concentration; $\mathrm{NB}=$ normal boron concentration.

Nutritional responses of citrus to low $p H$. Low $\mathrm{pH}$ not only affects the availability of soil mineral nutrients but also impacts the absorption of mineral nutrients by the roots. Previous studies have shown that soil acidification affected the availability of soil $\mathrm{N}, \mathrm{P}, \mathrm{Ca}, \mathrm{Mg}, \mathrm{S}, \mathrm{B}, \mathrm{Cu}$, and $\mathrm{Zn}$, and the levels of organic matter and cation exchange capacity, thereby inducing soil and leaf nutrient imbalances in 'Guanximiyou' pummelo (Citrus grandis) seedlings ( $\mathrm{Li}$ et al., 2015). In this work, nutrient solution with low $\mathrm{pH}(\mathrm{pH} 4.0,5.0$, and 6.0) culture was used for the 'HB' pummelo seedlings. The two effects of low $\mathrm{pH}$ were separated, and the work focused on investigating the effects of low $\mathrm{pH}$ on the absorption of mineral nutrients by the roots. The same method has also been used for researching rose (Roosta and Rezaei, 2014). B mainly exists as boric acid in the soil; therefore, its uptake by the root cells is significantly affected by various environmental factors such as soil $\mathrm{pH}$, soil clay content, and soil organic matter.

Soil $\mathrm{pH}$ is considered one of the most important factors affecting the soil B supply, but the soil B supply capacity does not increase with the increase in the $\mathrm{pH}$ value. Our results showed that the $\mathrm{B}$ concentration decreased significantly in all organs of the seedlings, and that no remarkable difference was observed at all $\mathrm{pH}$ values under Bdeficient conditions. However, the B concentrations decreased dramatically in the leaf and root at $\mathrm{pH} 4.0$ compared with the other $\mathrm{pH}$ values under normal $\mathrm{B}$ conditions (Fig. 4A-C). Similarly, a previous study also showed that the shoot $\mathrm{B}$ concentration increased with increased $\mathrm{B}$ and was greater at $\mathrm{pH} 6.0$ than at $\mathrm{pH} 8.0$ in broccoli (Brassica oleracea L.) (Smith et al., 2013). In this research, boric acid $\left(\mathrm{H}_{3} \mathrm{BO}_{3}\right)$ was used in the control nutrient solutions, and no $\mathrm{H}_{3} \mathrm{BO}_{3}$ was added to the B-deficient nutrient solutions. Results obtained from model plants have shown that $\mathrm{B}$ transport is a process mediated not only by passive diffusion but also by transporters whose activity is regulated in response to B conditions (Miwa and Fujiwara, 2010). Under normal B conditions, $\mathrm{H}_{3} \mathrm{BO}_{3}$ is absorbed into the root cell and transported to the xylem via passive diffusion. In contrast, under limited $\mathrm{B}$ conditions, $\mathrm{H}_{3} \mathrm{BO}_{3}$ is absorbed into the root cell and xylem loading by $\mathrm{B}$ transporters, such as BOR1, PIP1;1, NIP5;1, NIP6;1, and other aquaporin proteins in vascular plants, including citrus, occurs (An et al., 2012; Takano et al., 2001, 2002, 2006; Tanaka et al., 2008).
Interestingly, no remarkable differences were observed among all $\mathrm{pH}$ values under B deficiency conditions (Fig. 4A-C), which might be attributed to the lack of $\mathrm{H}_{3} \mathrm{BO}_{3}$ in the $\mathrm{B}$-deficient nutrient solutions.

The uptake of macronutrients $(\mathrm{P}, \mathrm{K}, \mathrm{Ca}$, and $\mathrm{Mg}$ ), which was detected in the leaf, stem, and root of the 'HB' pummelo seedlings, was also influenced by low $\mathrm{pH}$ stress under both normal and deficient $\mathrm{B}$ conditions (Fig. 5). $\mathrm{P}$ is a nutrient that is sensitive to soil $\mathrm{pH}$, and its optimum $\mathrm{pH}$ range for absorption ranges from 6.0 to 7.0. Therefore, its uptake by the roots is inhibited under both high and low $\mathrm{pH}$ (Marschner, 1995). $\mathrm{P}$ is absorbable in the form of initial orthophosphate $\left(\mathrm{H}_{2} \mathrm{PO}_{4}^{-}\right)$, but the ratio of $\mathrm{H}_{2} \mathrm{PO}_{4}^{-} / \mathrm{HPO}_{4}{ }^{2-}$ differs under different $\mathrm{pH}$ values, and the absorption efficiency also varies in the root cells (Shekofteh, 2009). In our work, the P concentration increased with the increase in $\mathrm{pH}$ from 4.0 to 6.0 in the leaf under normal B conditions, whereas no significant change was observed in the stem and root (Fig. 5A-C). These results corroborate those of previous studies of rose (Roosta and Rezaei, 2014).

$\mathrm{K}, \mathrm{Ca}$, and $\mathrm{Mg}$ are absorbed in the form of $\mathrm{K}^{+}, \mathrm{Ca}^{2+}$, and $\mathrm{Mg}^{2+}$ by the plant root, respectively. In this work, no significant differences in these nutrients were observed between $\mathrm{pH}$ 4.0 and 5.0 in the roots under normal B conditions, but the concentrations under the former ( $\mathrm{pH} 4.0$ and 5.0) treatment were remarkably lower than they were at $\mathrm{pH}$ 6.0. However, no significant differences were detected in the leaf and stem, which corroborates the results of previous research of trifoliate orange (Zhou et al., 2014). At the cellular level, a high $\mathrm{H}^{+}$concentration (low $\mathrm{pH}$ ) not only competes for binding sites with $\mathrm{K}^{+}$but also decreases the efficiency of the $\mathrm{H}^{+}$ current in the plasma membrane of the root cell. Additionally, internal and external $\mathrm{pH}$ have a role in the regulation of $\mathrm{K}^{+}$secretion into the xylem sap. Previous studies have shown that the activity of $\mathrm{K}$ channels in plant root cells is also affected by internal and external pH (Lancombe et al., 2000). As a result, the absorption of $\mathrm{K}$ is inhibited in the root under low $\mathrm{pH}$ conditions. Under normal $\mathrm{B}$ conditions, the root $\mathrm{Ca}$ concentration decreased sharply at $\mathrm{pH} 4.0$ compared with that at $\mathrm{pH} 6.0$ in this work (Fig. 5G-I). The same tendency was found in $\mathrm{Mg}$ concentrations under normal B conditions (Fig. 5G-I). This was mainly attributed to the inhibition of the cation exchange capacity of the root cells by high $\mathrm{H}^{+}$concentrations under low $\mathrm{pH}$ conditions. $\mathrm{Ca}$ is primarily absorbed by the root apexes where the Casparian band is not yet created. Therefore, the decreased root $\mathrm{Ca}$ concentrations may be caused by the inhibition of root development under low $\mathrm{pH}$ stress (Fig. 3). Recent studies have confirmed that low $\mathrm{pH}$ affected reactive oxygen species and methylglyoxal metabolisms more in roots than in the leaves of 'Xuegan' (Citrus sinensis) and 'Sour pummelo' (Citrus grandis). The most seriously impaired ascorbate metabolism in roots was suggested to have a role 
in low $\mathrm{pH}$-induced root death and growth inhibition (Long et al., 2019).

Micronutrient (except B) absorption in the rhizosphere is influenced by a variety of complex factors, such as soil properties (including soil $\mathrm{pH}$ ), plant properties, and interactions of the roots with microorganisms. In this work, we focused on the Fe, Mn, and $\mathrm{Zn}$ uptake under low $\mathrm{pH}$. Previous studies have shown that the root rhizosphere $\mathrm{pH}$ significantly influences the $\mathrm{Fe}, \mathrm{Mn}$, and $\mathrm{Zn}$ uptake (Chen et al., 2002; Marschner, 1995). In this study, leaf and stem Fe concentrations were decreased significantly at $\mathrm{pH} 4.0$ under both normal and deficient $\mathrm{B}$ conditions (Fig. 4). High $\mathrm{pH}$, even in neutral conditions, can affect $\mathrm{Fe}$ uptake and translocation into the plant. Interestingly, at $\mathrm{pH} 4.0$, the $\mathrm{Fe}$ concentration was also decreased significantly under both normal and deficient $\mathrm{B}$ conditions. This result may be caused by the inhibition of root growth and development at low $\mathrm{pH}$ (Fig. 3).

Nutritional responses of citrus to $B$ deficiency. As shown in Figs. 4 and 5, both $\mathrm{B}$ and other mineral nutrient concentrations were influenced significantly by B deficiency stress in 'HB' pummelo seedlings. Similar results have also been reported in other citrus species, such as 'Newhall' navel orange (C. sinensis), trifoliate orange (Poncirus trifoliata), carrizo citrange $(C$. sinensis $\times P$. trifoliata), red tangerine (C. reticulata), cleopatra mandarin (C. reshni), fragrant citrus $(C$. junos), and sour orange (C. aurantium) (Liu et al., 2011a; Mei et al., 2016; Zhou et al., 2014).

Previous studies have shown that not only is $\mathrm{P}$ concentration significantly affected by $\mathrm{B}$ status (deficiency or toxicity), but B concentration is also dramatically influenced by $\mathrm{P}$ availability (Wang et al., 2018; Zhou et al., 2014). In this study, the $P$ concentration significantly decreased in all organs of the seedlings under B-deficient conditions, particularly in the leaf at pH 6.0 (Fig. 5A-C). Furthermore, the growth and development of the roots were inhibited dramatically by $\mathrm{B}$ deficiency stress (Fig. 3). P is believed to be an essential mineral nutrient for plant growth, cell energy homeostasis (ATP), nucleic acid formation, and reversible protein phosphorylation (Maathuis, 2009); furthermore, P deficiency can induce root growth and development (Lisa et al., 2001; LópezBucio et al., 2003). Previous studies have suggested that the growth and development of citrus roots are significantly inhibited under B deficiency stress via decreased P concentration (Zhou et al., 2014). Our findings are in agreement with those of previous studies.

$\mathrm{Ca}$ is a main chemical component of the cell wall, and more than $90 \%$ of B in plants exist in the cell wall. Some reports indicate that $\mathrm{Ca}$ and $\mathrm{B}$ promote each other (Ramon et al., 2000), whereas other studies suggest that a mutual antagonism exists between them. Several $\mathrm{Ca}_{2}{ }^{+}$channel/transporter genes were upregulated in response to shortterm B deficiency in Arabidopsis roots
(Quiles-Pando et al., 2013). It was recently shown that B-deprived tobacco BY-2 cells took-up more $\mathrm{Ca}_{2}{ }^{+}$than the control cells (Koshiba et al., 2010). Another study showed that $\mathrm{B}$ deficiency increased the levels of cytosolic $\mathrm{Ca}_{2}{ }^{+}$in Arabidopsis roots (QuilesPando et al., 2013). All these results suggest that the $\mathrm{Ca}$ concentration could be increased by $\mathrm{B}$ deficiency. $\mathrm{Ca}$ is a crucial secondary intracellular messenger that has a major role in the plant response to stress. Moreover, $\mathrm{Ca}_{2}{ }^{+}$can bind to $\mathrm{Ca}_{2}{ }^{+}$sensors, such as calmodulins (CaMs) and calmodulin-like proteins (CMLs) (Sanders et al., 2002). Therefore, the lack of decrease in Ca concentration in the seedling might be associated with the response to B deficiency.

In this study, $\mathrm{Fe}$ and $\mathrm{Mn}$, which are key micronutrients for photosynthesis in higher plants, were also decreased by B deficiency stress (Fig. 4). These results are similar to the findings of current research of other citrus (Mei et al., 2016; Zhou et al., 2014). Previous studies also suggested that the inhibition of leaf photosynthesis could be caused by decreased concentrations of $\mathrm{Mg}, \mathrm{Fe}$, and $\mathrm{Mn}$ in the citrus leaves (Zhou et al., 2014). It is worth noting that the effect of B deficiency on the $\mathrm{Zn}$ concentration is different in the leaves of 'Newhall' navel orange grafted on two different rootstocks under B deficiency conditions (Liu et al., 2011b). The $\mathrm{Zn}$ concentration was decreased significantly under B deficiency in both old and new leaves of a citrus plant grafted on carrizo citrange, but not in trifoliate orange. This result might indicate that carrizo citrange is more tolerant than trifoliate orange to B deficiency stress (Zhou et al., 2015). Our results also corroborate those of previous studies (Fig. 4).

\section{Conclusion}

In conclusion, low $\mathrm{pH}$ and $\mathrm{B}$ deficiency stress not only affected plant growth and development in both the aboveground and belowground parts of the 'HB' pummelo seedlings but also impacted the concentrations of $\mathrm{B}$ and other mineral nutrients. Plant biomass, leaf area, seedling height, and root traits were remarkably decreased by low $\mathrm{pH}$ and $\mathrm{B}$ deficiency stresses, and these parameters were extremely reduced with the decrease in $\mathrm{pH}$ level. After 12 weeks of treatment, typical B deficiency symptoms of citrus leaf were observed, with more severe symptoms observed at $\mathrm{pH} 5.0$ than at $\mathrm{pH}$ 6.0. The leaf gas exchange parameter measurements showed that leaf photosynthesis was significantly inhibited under both low $\mathrm{pH}$ and $\mathrm{B}$ deficiency conditions. It is worth noting that the lower the $\mathrm{pH}$ level, the greater the inhibition under both normal and deficient $\mathrm{B}$ conditions. Further investigations of the mineral nutrient concentration results showed that under both low $\mathrm{pH}$ and $\mathrm{B}$ deficiency conditions, not only the $\mathrm{B}$ concentration but also the other mineral nutrient concentrations were influenced dramatically, especially at $\mathrm{pH} 4.0$ and 5.0. Based on the physiological and nutritional performances of the ' $\mathrm{HB}$ ' pummelo seedlings, these results indicate that low $\mathrm{pH}$ can alleviate the effects of $\mathrm{B}$ deficiency to a certain extent.

\section{Literature Cited}

An, J.C., Y.Z. Liu, C.Q. Yang, G.F. Zhou, Q.J. Wei, and S.A. Peng. 2012. Isolation and expression analysis of CiNIP5, a citrus boron transport gene involved in tolerance to boron deficiency. Sci. Hort. 142:149-154.

Bolaños, L., K. Lukaszewski, I. Bonilla, and D. Blevins. 2004. Why boron? Plant Physiol. Biochem. 42:907-912.

Brown, P.H., N. Bellaloui, M.A. Wimmer, E.S. Bassil, J. Ruiz, H. Hu, H. Pfeffer, F. Dannel, and V. Römheld. 2002. Boron in plant biology. Plant Biol. 4:205-223.

Camacho-Cristóbal, J.J., M.B. Herrera-Rodríguez, V.M. Beato, J. Rexach, M.T. Navarro-Gochicoa, J.M. Maldonado, and A. González-Fontes. 2008. The expression of several cell wall-related genes in Arabidopsis roots is down-regulated under boron deficiency. Environ. Exp. Bot. 63:351358.

Chen, F., J.W. Lu, D.B. Liu, and K.Y. Wan. 2010. Investigation on soil fertility and citrus yield in south China. 19th World Congress of Soil Science, Brisbane, Australia.

Chen, L.S., S. Han, Y.P. Qi, and L.T. Yang. 2012. Boron stresses and tolerance in citrus. Afr. J. Biotechnol. 11:5961-5969.

Chen, Y.L., S.J. Han, and Y.M. Zhou. 2002. The rhizosphere $\mathrm{pH}$ change of Pinus koraiensis seedlings as affected by $\mathrm{N}$ sources of different levels and its effect on the availability and uptake of $\mathrm{Fe}, \mathrm{Mn}, \mathrm{Cu}$ and $\mathrm{Zn}$. J. For. Res. 13:37-40.

Dell, B. and L.B. Huang. 1997. Physiological response of plants to low boron. Plant Soil 193:103-120.

Forde, B. and H. Lorenzo. 2001. The nutritional control of root development. Plant Soil 232:5168.

Goldberg, S., S.M. Lesch, and D.L. Suarez. 2000. Predicting boron adsorption by soils using soil chemical parameters in the constant capacitance model. Soil Sci. Soc. Amer. J. 64:13561363

Guo, C.X., Z.Y. Pan, and S.A. Peng. 2016. Effect of biochar on the growth of Poncirus trifoliata (L.) Raf. seedlings in Gannan acidic red soil. Soil Sci. Plant Nutr. 62:194-200.

Guo, J.H., X.J. Liu, Y. Zhang, J.L. Shen, W.X. Han, W.F. Zhang, P. Christie, K.W. Goulding, P.M. Vitousek, and F.S. Zhang. 2010. Significant acidification in major Chinese croplands. Science 327:1008-1010.

Gupta, R.K., R.A. Sharma, and B.R. Singh. 1985. Growth parameters of safflower (Carthamus tinctorius) in relation to changing soil water potential. Indian J. Plant Physiol. 8:1-7.

Han, S., L.S. Chen, H.X. Jiang, B.R. Smith, L.T. Yang, and C.Y. Xie. 2008. Boron deficiency decreases growth and photosynthesis, and increases starch and hexoses in leaves of citrus seedlings. J. Plant Physiol. 165:1330-1341.

Han, S., T. Ning, H.X. Jiang, L.T. Yang, Y. Li, and L.S. Chen. 2009. $\mathrm{CO}_{2}$ assimilation, photosystem II photochemistry, carbohydrate metabolism and antioxidant system of citrus leaves in response to boron stress. Plant Sci. 176:143153.

Hoagland, D.R. and D.S. Arnon. 1950. The water culture method for growing plants without soil. California Agricultural Experiment Station Circular 347:305-311. 
Hodge, A., G. Berta, C. Doussan, F. Merchan, and M. Crespi. 2009. Plant root growth, architecture and function. Plant Soil 321:153-187.

Koshiba, T., M. Kobayashi, A. Ishihara, and T. Matoh. 2010. Boron nutrition of cultured tobacco BY-2 cells. VI. Calcium is involved in early responses to boron deprivation. Plant Cell Physiol. 51:323-327.

Lancombe, B., G. Pilot, G. Frédéric, S. Hervé, and J.B. Thibaud. 2000. pH control of the plant outwardly-rectifying potassium channel SKOR. FEBS Lett. 466:351-354.

Läuchli, A. and S.R. Grattan. 2012. Soil pH extremes, p. 194-209. In: S. Shabala (eds.). Plant stress physiology. CAB International, Oxfordshire, UK.

Liang, Q.M., J. Xue, Y.L. Fan, X. Li, and L.Z. Peng. 2010. Studies on soil acidification of navel orange orchards in Ganzhou city, Jiangxi province. South China Fruits 39:6-8, 13.

Li, Q.H., Y.Z. Liu, Z.Y. Pan, S. Xie, and S.A. Peng. 2016. Boron deficiency alters root growth and development and interacts with auxin metabolism by influencing the expression of auxin synthesis and transport genes. Biotechnol. Biotec. Eq. 30:661-668.

Li, Y., M.Q. Han, F. Lin, Y. Ten, J. Lin, D.H. Zhu, P. Guo, Y.B. Weng, and L.S. Chen. 2015. Soil chemical properties, 'Guanximiyou' pummelo leaf mineral nutrient status and fruit quality in the southern region of Fujian province, China. J. Soil Sci. Plant Nutr. 15(3):615-628.

Lisa, C.W., P.C.R. Sebastien, and H.F. Ribriowx Alasrair. 2001. Phosphate availability regulates root system architecture in Arabidopsis. Plant Physiol. 126:875-882.

Liu, G.D., C.C. Jiang, and Y.H. Wang. 2011a. Distribution of boron and its forms in young 'Newhall' navel orange (Citrus sinensis Osb.) plants grafted on two rootstocks in response to deficient and excessive boron. J. Soil Sci. Plant Nutr. 57:93-104.

Liu, G.D., C.C. Jiang, Y.H. Wang, S.A. Peng, B.L. Zhong, Q.L. Ceng, and S.X. Yuan. $2011 \mathrm{~b}$. Changes in mineral element contents of 'Newhall' navel orange (Citrus sinensis osb.) grafted on two different rootstocks under boron deficiency. Plant Nutr. Fert. Sci. 17:180-185.

Long, A., J. Zhang, L.T. Yang, X. Ye, N.W. Lai, L.L. Tan, D. Lin, and L.S. Chen. 2017. Effects of low $\mathrm{pH}$ on photosynthesis, related physiological parameters and nutrient profile of citrus. Front. Plant Sci. 8:185.

Long, A., W.L. Huang, Y.P. Qi, L.T. Yang, N.W. Lai, J.X. Guo, and L.S. Chen. 2019. Low pH effects on reactive oxygen species and methylglyoxal metabolisms in Citrus roots and leaves. BMC Plant Biol. 19:477.

López-Bucio, J., A. Cruz-Ramirez, and L. HerreraEstrella. 2003. The role of nutrient availability in regulating root architecture. Curr. Opin. Plant Biol. 6:280-287.

Lu, Y.B., L.T. Yang, Y. Li, J. Xu, T.T. Liao, Y.B. Chen, and L.S. Chen. 2014. Effects of boron deficiency on major metabolites, key enzymes and gas exchange in leaves and roots of Citrus sinensis seedlings. Tree Physiol. 34:608-618.

Maathuis, F.J.M. 2009. Physiological functions of mineral macronutrients. Curr. Opin. Plant Biol. 12:250-258.

Major, J., M. Rondon, D. Molina, S.J. Riha, and J. Lehmann. 2010. Maize yield and nutrition during 4 years after biochar application to a
Colombian savanna oxisol. Plant Soil 333:117128.

Marschner, H. 1995. Mineral nutrition of higher plants. 2nd ed. Academic Press, London, UK.

Mei, L., Q.H. Li, H. Wang, O. Sheng, and S.A. Peng. 2016. Boron deficiency affects root vessel anatomy and mineral nutrient allocation of poncirus trifoliata (L.) raf. Acta Physiol. Plant. 38:1-8.

Miwa, K. and T. Fujiwara. 2010. Boron transport in plants: Co-ordinated regulation of transporters. Ann. Bot-london 105:1103-1108.

Papadakis, I.E., N. Dimassi, A.M. Bosabalidis, I.N Therios, A. Patakas, and A. Giannakoula. 2004. Boron toxicity in 'Clementine' mandarin plants grafted on two rootstocks. Plant Sci. 166:539547.

Quiles-Pando, C., J. Rexach, M.T. Navarro-Gochicoa, J.J. Camacho-Cristóbal, M.B. Herrera-Rodríguez, and A. González-Fontes. 2013. Boron deficiency increases the levels of cytosolic $\mathrm{Ca}_{2}^{+}$and expression of $\mathrm{Ca}_{2}{ }^{+}$-related genes in Arabidopsis thaliana roots. Plant Physiol. Biochem. 65:55-60.

Ramon, O.C., E. Elvira, and S.M. Jose. 2000. Boron and calcium distribution in nitrogenfixing pea plants. Plant Sci. 151:163-170.

Roosta, H.R. and I. Rezaei. 2014. Effect of Nutrient solution $\mathrm{pH}$ on the vegetative and reproductive growth and physiological characteristics of Rose cv. 'Grand Gala' in hydroponic system. J. Plant Nutr. 37:2179-2194.

Russell, A.E.L.D. 2006. Nitrogen fertilization and cropping system impacts on soil quality in Midwestern Mollisols. Soil Sci. Soc. Amer. J. 1:249-255.

Sanders, D., J. Pelloux, C. Brownlee, and J.F. Harper. 2002. Calcium at the crossroads of signaling. Plant Cell 14:S401-S417.

Shekofteh, H. 2009. Plant nutrition in horticulture. Islamic Azad University, Jiroft Branch Press, Jirouft, Iran.

Sheng, O., S.W. Song, Y.J. Chen, S.A. Peng, and X.X. Deng. 2008. Effects of exogenous boron supply on growth, B accumulation and distribution of two navel orange cultivars. Trees 23:59-68.

Sheng, O., S.W. Song, S.A. Peng, and X.X. Deng. 2009. The effects of low boron on growth, gas exchange, boron concentration and distribution of 'Newhall' navel orange (Citrus sinensis Osb.) plants grafted on two rootstocks. Scientia Hort. 121:278-283.

Shorrocks, V.M. 1997. The occurrence and correction of boron deficiency. Plant Soil 193:121148.

Smith, T.E., S.R. Grattan, C.M. Grieve, J.A. Poss, A.E. Läuchli, and D.L. Suarez. 2013. pH dependent salinity-boron interactions impact yield, biomass, evapotranspiration and boron uptake in broccoli (Brassica oleracea L.). Plant Soil 370:541-554.

Storey, R. and M.T. Treeby. 2000. Nutrient uptake into navel orange during fruit development. J. Hort. Sci. Biotechnol. 77:91-99.

Sumner, M.E. and A.D. Noble. 2003. Soil acidification: The world story, p. 1-28. In: Z. Rengel (eds.). Handbook of soil acidity. Marcel Dekker, New York, NY.

Takano, J., K. Noguchi, M. Yasumori, M. Kobayashi, Z. Gajdos, K. Miwa, H. Hayashi, T. Yoneyama, and T. Fujiwara. 2002. Arabidopsis boron transporter for xylem loading. Nature 420: 337-340.

Takano, J., M. Wada, U. Ludewig, G. Schaaf, N. Von Wirén, and T. Fujiwara. 2006. The Arab- idopsis major intrinsic protein NIP5;1 is essential for efficient boron uptake and plant development under boron limitation. Plant Cell 18:1498-1509.

Takano, J., M. Yamagami, K. Noguchi, H. Hayashi, and T. Fujiwara. 2001. Preferential translocation of boron to young leaves in Arabidopsis thaliana regulated by the $B O R 1$ gene. Soil Sci. Plant Nutr. 47:345-357.

Tanaka, M., I.S. Wallace, J. Takano, D.M. Roberts, and T. Fujiwara. 2008. NIP6;1 is a boric acid channel for preferential transport of boron to growing shoot tissues in Arabidopsis. Plant Cell 20:2860-2875.

Van Zwieten, L., S. Kimber, S. Morris, K.Y. Chan, A. Downie, J. Rust, S. Joseph, and A. Cowie. 2010. Effects of biochar from slow pyrolysis of papermill waste on agronomic performance and soil fertility. Plant Soil 327:235-246.

Wang, Y.L., N. Clarke, and A.F. Øgaard. 2018. Low phosphorus availability increases shoot boron concentration in canola and potato but not in wheat. Plant Soil Environ. 64:564-570.

Wang, N.N., C.Q. Yang, Z.Y. Pang, Y.Z. Liu, and S.A. Peng. 2015. Boron deficiency in woody plants: Various responses and tolerance mechanisms. Front. Plant Sci. 6:916.

Wu, X.W., X.P. Lu, M. Riaz, L. Yan, and C.C. Jiang. 2018. Boron deficiency and toxicity altered the subcellular structure and cell wall composition architecture in two citrus rootstocks. Scientia Hort. 238:147-154.

Yang, C.Q., Y.Z. Liu, J.C. An, S. Li, L.F. Jin, G.F. Zhou, Q.J. Wei, H.Q. Yan, N.N. Wang, L.N. $\mathrm{Fu}, \mathrm{X}$. Liu, X.M. Hu, T.S. Yan, and S.A. Peng. 2013. Digital gene expression analysis of corky split vein caused by boron deficiency in 'Newhall' Navel Orange (Citrus sinensis Osbeck) for selecting differentially expressed genes related to vascular hypertrophy. Plos One 8:e65737.

Yang, C.Q., T. Liu, F.X. Bai, N.N. Wang, Z.Y. Pan, X. Yan, and S.A. Peng. 2015. miRNAome analysis associated with anatomic and transcriptomic investigations reveal the polar exhibition of corky split vein in boron deficient Citrus sinensis. Mol. Genet. Genomics 290: 1639-1657.

Zhang, H.M., B.R. Wang, M.G. Xu, and T.L. Fan. 2009. Crop yield and soil responses to longterm fertilization on a red soil in Southern China. Pedosphere 19:199-207.

Zhang, J., Q. Li, Y.P. Qi, W.L. Huang, L.T. Yang, N.W. Lai, X. Ye, and L.S. Chen. 2018. Low $\mathrm{pH}$-responsive proteins revealed by a $2-\mathrm{DE}$ based MS approach and related physiological responses in Citrus leaves. BMC Plant Biol. 18:188.

Zhou, G.F., B.X. Li, G. Guan, F.X. Yao, and G.D. Liu. 2018. Effects of acid and alkaline stresses on the growth, photosynthetic characteristics and mineral nutrition of Pummelo 'HB'. Chinese J. Trop. Agr. 38:1-8.

Zhou, G.F., Y.Z. Liu, O. Sheng, Q.J. Wei, C.Q. Yang, and S.A. Peng. 2015. Transcription profiles of boron-deficiency-responsive genes in citrus rootstock root by suppression subtractive hybridization and cDNA microarray. Front. Plant Sci. 5:795.

Zhou, G.F., S.A. Peng, Y.Z. Liu, Q.J. Wei, J. Han, and M.Z. Islam. 2014. The physiological and nutritional responses of seven different citrus rootstock seedlings to boron deficiency. Trees 28:295-307. 